\title{
Okul Yönetiminde Kayırmacılık ve Örgütsel Adalet Arasındaki İlişki: Afyonkarahisar İli Örneği ${ }^{1}$
}

DOI: $10.26466 /$ opus.633508

\author{
Ayşe Cesur* - Evrim Erol ${ }^{* *}$ \\ * Öğretmen, Bedriye-Kadir Uysal Orta Okulu, Uşak / Türkiye \\ E-Posta: aysecoskun1064@gmail.com \\ ORCID: $0000-0002-6131-9328$ \\ ** Dr. Öğr. Üyesi, Dumlupınar Üniversitesi, Kütahya / Türkiye \\ E-Posta: evrim.erol@dpu.edu.tr \\ ORCID: $0000-0001-5910-497 X$
}

$\ddot{O} z$

Bu çalışmada, öğretmenlerin okul yönetiminde kayırmacılık algıları ile örgütsel adalet algıları arasındaki ilişkinin belirlenmesi amaçlanmıştır. Çalışma tarama modelinde desenlenmiştir. Çalışmanın örneklemi basit seçkisiz örnekleme yöntemi ile belirlenmiş, 413 öğretmenden oluşmaktadır. Veriler, Örgütsel Adalet Ölçeği (Taşdan ve Yılmaz, 2008) ve Okul Yönetiminde Kayırmacllı Ölçeği (Erdem ve Meriç, 2012) kullanılarak anket yoluyla toplanmıştır. Çalışmada, $t$-testi, tek yönlü ANOVA testi, Pearson çarpım moment korelasyon katsayısı ve betimsel istatistikler kullanılmıştır. Elde edilen bulgulara göre, öğretmenler düşük düzeyde okul yönetiminde kayırmacılık algısına, yüksek düzeyde örgütsel adalet algısına sahiptir. Çalışmada, öğretmenlerin demografik özelliklerine göre örgütsel adalet algılarında cinsiyet değişkeni dışında (okul kademesi, branş ve yaş ve kıdem) farklılaşma bulunmazken, okul yönetiminde kayırmacılık algılarında farklılaşmalar saptanmıştır. Öğretmenlerin okul yönetiminde kayırmacılık algılarl, cinsiyet yaş ve kıdem değişkenlerine göre istatistiksel olarak anlaml farklılık gösterirken; okul kademesi ve branş değişkenlerine göre istatistiksel olarak anlaml farklllı göstermemektedir. Çalışmada, öğretmenlerin okul yönetiminde kayırmacılık algılarım belirleyen tüm boyutlar (planlama, örgütleme, koordinasyon ve değerlendirme) ile örgütsel adalet algıları arasında düşük düzeyde, negatif yönlü anlamlı ilişkiler olduğ u saptanmıştır.

Anahtar Kelimeler: Kayırmacılı, Örgütsel adalet, Okul yönetimi, Öğretmen

\footnotetext{
${ }^{1}$ Bu çalışma aynı isimli yüksek lisans tezinden üretilmiştir.
} 


\title{
The Relationship Between Favoritism in School Management and Organizational Justice The Sample of Afyonkarahisar ${ }^{2}$
}

\begin{abstract}
In this study, it was aimed to determine the relationship between the teachers' perceptions of favoritism in school management and organizational justice. The study was designed in the survey model. The sample of the study determined by simple random sampling method is consisted of 413 teachers in the city center of Afyonkarahisar. The study data were collected through Organizational Justice Scale (Taşdan and Yılmaz, 2008) and Scale on Favoritism in School Management (Erdem and Meriç, 2012). In the study, $t$-test for comparisons, one-way variance analysis, Pearson Product Moment Correlation Coefficient and descriptive statistics were used. According to the findings obtained in the study; teachers have a high level of organizational justice perception and a low level of favoritism perception in school management. In the study, according to the demographic characteristics of teachers, it was stated that there were no significant differences in their perceptions of organizational justice except for gender variable (school type, branch, age and seniority) while there were significant differences in their perceptions of favoritism in school management. Whereas the teachers' perceptions of organizational justice show statistically significant differences according to the gender variance, they don't show statistically significant differences according to the school type, branch, age, and seniority variances. In the study, it was found out that there were low-level, in the negative direction, significant relationships between the whole dimensions determining the teachers' perceptions of favoritism in school management and their perceptions of organizational justice.
\end{abstract}

Keywords: Favoritism, Organizational justice, School management, Teacher

\footnotetext{
${ }^{2}$ This study has been produced from the Master's Thesis with the same name.
} 


\section{Giriş}

Genel anlamda bir kişi veya grubun çıkar sağlamasına yönelik olarak yapılan hak ve adaletten sapma eğilimi olarak tanımlanan kayırmacılık(Erdem, 2010), sosyal sistemlerin olduğu her alanda karşımıza çıkabilen, varlığı benimsenen ve genellikle meşruluğu kabul edilen bir durumdur (Özkanan ve Erdem, 2014). Okul yönetiminde kayırmacılık ise okul yöneticilerinin, okul iş ve işlemlerinde kendi menfaatleri doğrultusunda etik dışı bir şekilde hak ve adaletten saparak arkadaşlık (asker, okul, mahalle, hemşeri, vb.), akrabalık/yakınlık (amca, dayı yeğen, kirve, meslek, aşiret, ırk, komşuluk, vb.) ve aynılık (din, mezhep, tarikat, köy, toprak, parti, sendika, memleket, mahalle, cinsiyet, vb.) gibi sebeplerle bazı çalışanlara yönelik destekleme, koruma, kollama, himaye etme vb. gibi tutum ve davranışları içermektredir (Demirbilek, 2018). $\mathrm{Bu}$ bağlamda okul içerisinde etik olmayan ve adalet dışı bir uygulama olan kayırmacı tutum ve davranışların eşitsizliğe, buna bağlı olarak öğretmenlerin adalet algılarında düşüşe yol açacağı düşünülmektedir. Bu doğrultuda çalışmada kayırmacılık ve örgütsel adalet algısı arasındaki ilişkiler ilköğretim kurumlarında görev yapan öğretmenler üzerinde incelenmiştir.

\section{Kayırmacilık kavramı}

İngilizcede favoritism olarak kullanılan kayırmacılık kavramı toplum arasinda genellikle "iltimas geçme, kollama, torpil yapma" gibi anlamlarda kullanılmaktadır (Büte, 2011). Özsemerci (2002) ise kayırmacılığın "adamını bularak iş gördürme, belli kişi veya grubu ön planda tutma" ve halk dili şekliyle "torpil" terimlerine karşılık geldiğini ifade etmektedir. Yönetim alanyazınında etik dışı bir davranış olarak tanımlanan kayırmacılık (Polat ve Kazak, 2014), kamu görevlilerinin duygusal bağlılıklar ve yükümlülüklerden dolayı görevlerini kötüye kullanarak çevrelerindeki yakın kişilere tanıdıkları ayrıcalık şeklinde tanımlanmaktadır (Saylı ve Kızıldağ, 2007).

Kayırmacı ilişkilerin temelinde kayıran, kayrılan ve kayırılmayan olmak üzere üç tarafın varlığından söz edilmektedir. Kayıran ve kayrılan arasındaki ilişki yapısal olarak hiyerarşik bir özelliğe sahiptir. Bu hiyerarşinin alt tabanında korunan, şartları kolaylaştırılan ve desteklenen taraf yer alırken; koruyup gözeten taraf ise hiyerarşinin üstünde, tepe noktasında bulunmaktadır. 
Kayrılan, kayıran tarafa vicdanen borçlu hissetmekte, minnet duymakta, saygıda kusur etmemek için rüşvet ve hediyelerle bağlılığını göstermeye çalışmaktadır. Kayıran, zamanla elde ettiği mal, mülk, saygınlık, iktidar ve ün ile statüsünü güçlendirip hiyerarşideki yerini daha sağlam hale getirirken kayrrlan geçici somut imkân ve olanaklar elde etmektedir (İlhan ve Aytaç, 2010). Görüldüğü gibi her iki taraf da birbirlerinden karşılıklı fayda sağlamaktadır. Kayırma sisteminde bir de kayrılmayan taraf vardır ki bu kişiler sistemin mağdur ettiği taraf olarak görülmektedir. Kayrılmayan bireyler kaynakların dağıtımı noktasında karşılaştıkları adil ve eşit olmayan uygulamalar yüzünden daha az çalışma, daha fazla devamsızlık yapma, grev yapma, işi bırakma ve hatta hırsızlık gibi örgüte zarar verici etik dışı davranışlarda bulunabilirler. Kayrılan ve kayrılmayan çalışanlar birbirlerine güvenmedikleri için kayırmacı uygulamaların görüldüğü örgütlerde kendi kişisel çıarları doğrultusunda kimi zaman yönetime yakın kimi zamanda uzak olmayı tercih ederler. Bu tür bir örgütsel ortamda sistemli çalışma ve bilgi paylaşımı pek mümkün olmayacağından çalışanların verimlilikleri, performansları ve motivasyonları düşecek, bu da örgütsel amaçları olumsuz etkileyecektir (Özler ve Büyükarslan, 2011).

Alanyazın incelendiğinde kayırmacılığın farklı yazarlar tarafından farklı alt başlıklarda ele alındığı görülmektedir. Yıldırım (2013) kayırmacılığı nepotizm ve kronizm olmak üzere ikiye ayırmış, siyasal kayırmacılı̆̆ı, hizmet kayırmacilığını ve gönül yapmayı (suvasyon) nepotizmin alt alanları olarak incelemiştir. Aydoğan (2009) ile Polat ve Kazak (2014) kayırmacilığı kronizm (eş-dost kayırmacilığı), patronaj ve nepotizm (akraba kayırmacılı̆̆ı) olarak üç alt alana ayırmıştır. Özkanan ve Erdem (2014) kayırmacilı̆̆ı adam kayırmacılığı ve siyasal kayırmacılık altında iki temel başlıkta toplamış; adam kayırmacılığını nepotizm ve kronizm, siyasal kayırmacılığı ise patronaj, hizmet kayırmacılığı ve klientalizm olarak alt alanlara ayırmıştır. Kayırmacılık türlerini patronaj, nepotizm, cinsel kayırmacılık, partizanlık, hizmet kayırmacılığı ve kronizm olarak altı başlık altında inceleyerek en geniş anlamda ifade eden araştırmacı ise Meriç (2012) olmuştur.

Nepotizm, bireylerin beceri, yetenek, bilgi ve diploma gibi niteliklerine bakılmadan yalnızca akrabalık unsurları esas alınıp istihdam edilmesi ya da göre- 
vinde yükselmesi olarak adlandırılmaktadır (Aytaç, 2010). Nepotizmin yoğun olarak görüldüğü toplumlar geleneksel bağların ve ilişkilerin güçlü olduğu toplumlardır.

Kronizm, eş-dost ve arkadaşlara yetenek, beceri ve tecrübelerine bakılmaks1zın yapılan bir ayrıcalıktır (Khatri, Fuei ve Geok,2008). Çoğunlukla bir kamu görevlisinin kendi eş-dost ve arkadaşlarının kamu kurumlarına yerleştirilmesi, bir üst seviyeye yükseltilmesi veya yurt dışında görevlendirilmesi gibi bazı imtiyazlardan faydalanması şeklinde meydana gelmektedir (Aktan, 2001).

Partizanlık, iktidarın partizanca davranarak kendi seçmenlerini başka parti taraftarlarına göre devlet imkânlarından haksız bir şekilde daha fazla yararlandırmasıdır (Özsemerci, 2002).

Patronaj, siyasi süreçte siyasi partilerin iktidar olduktan sonra özellikle kamudaki üst düzey bürokratik makamlara ideolojik veya nepotik ilişkiler temelinde kendilerine yakın kişileri atamalarına denilmektedir. Patronaj, partizanlığı da kapsayan daha geniş bir kavramdır. Partizanlığın patronajdan farkı, içerisinde siyasi yandaşlı̆̆ın yanı sıra bir nebze de olsa liyakati barındırmasıdır. Oysaki, patronajda bu liyakati görmek pek de mümkün olamamaktadır (Güven, 1976).

Hizmet kayırmacılı̆̆ı, iktidarın bir sonraki seçimde başarılı olmak amacıyla devletin sunduğu imkânları dengeli bir bütçe dağılımı yapmadan seçim bölgelerine ayırma durumudur. Hizmet kayırmacılığı nepotizm ve kronizm gibi insanoğlunun doğası gereği farkında olmadan yaptığı bir kayırmacılık türüdür (Andvig, Fjeldstad, Amundsen, Sissener ve Soreide, 2001).

Cinsel kayırmacılık, özellikle yöneticilerin aralarında gönül bağı kurdukları veya cinsel birliktelik yaşadıkları kişileri örgütteki diğer çalışanlardan ayrı tutmaları, onlara pozitif ayrımcılık tanımalarıdır (Meriç ve Erdem, 2013). Örgütlerde cinsel kayırmacılık işe alma süreçlerinde, terfi durumlarında ve görev dağılım aşamalarında kendini göstermektedir. Bu ilişki genellikle personel ile üst yönetimdeki müdür veya yetkili arasında rızaya dayanan cinsel romantik durumdur (Tol, 1991). 
Kayırmacılığın farklı türleri bulunmakla birlikte her bir tür kendi içinde ahlaki, sosyal, bireysel, kuramsal, ekonomik ve siyasal olmak üzere pek çok olumsuz sonuca sahiptir. Çoğunlukla kamu örgütlerinde ortaya çkan bir uygulama olarak kabul edilse de kayırmacılık, resmi/özel veya formal/informal tüm örgütlerde yaygın olarak görülmekle birlikte sosyal sistemin hemen her alanında zamanla kanıksanarak doğal karşılanır bir hal almıştır.

\section{Örgütsel adalet kavramı}

Çalışanın örgütüne yönelik adalet algısı olarak tanımlanan örgütsel adalet, örgütsel işleyişte ne derece adil davranıldığı konusunda çalışan algılarını ve bu algıların örgütü nasıl etkilediğini kapsayan bir terimdir (Greenberg, 1996; Çöp, 2008). Ceza ve ödül ile terfi ve ücretlerin dağıtımında kullanılan kriterler ile bu kriterlerin nasıl belirlendiği ve çalışanlara nasıl iletildiği örgütsel adaletin göstergelerindendir (Karacaoğlu ve Yörük, 2012). Ayrıca, örgütsel adalet etik ve adaletli uygulamaların örgüt içinde hâkimiyet kurmasını ve teşvikini içermektedir. Örgüt içerisinde belirlenen hedefler doğrultusunda standartların oluşturulması, işleyişi ve bu standartların çalışanlar üzerindeki etkilerini içeren örgütsel adalet; dağıtım, prosedürel, etkileşim boyutlarından oluşan bir süreçtir.

Dă̆ıtım adaleti, örgütsel ödül, görev ve sorumlulukların her bir çalışana katkısı oranında paylaştırmasını ifade eden bir kavramdır (Greenberg, 1990). Cohen (1987) dağıtım adaletini elde edilen verilere göre ödüllerin hakkaniyetine bağlı olan bir olgu olarak nitelendirerek; mallar, cezalar, hizmetler, görevler, statüler, ödüller, roller, fırsatlar, ücretler ve terfiler gibi her türlü kazanımın bireyler arasındaki paylaşıma konu edinmesi gerektiğini vurgulamıştir.

Prosedürel (işlemsel) adalet, ücret, terfi, performans ve çalışma koşullarına ilişkin kriterlerin oluşturulması ve adil bir şekilde uygulanması için gerekli prosedür, yöntem ve stratejiler olarak adlandırılmaktadır (Greenberg, 1990). Prosedürel adalet, örgüt içerisinde çalışanların gösterdikleri çaba ve performansa bağlı olarak hak ettikleri ödüllerin belirlenmesi ve dağıtımı ile ilgilenirken aynı zamanda bu kazanımların dağıtımında alınan kararların ve uy- 
gulanılan prosedürlerin çalışanlar açısından ne derece adil algilandığı üzerinde durur (Cropanzano, Bowen ve Gilliland, 2007). Prosedürel adalet, örgütsel kazanımların dağıtılmasındaki süreçleri tüm boyutlarıyla ele alırken dağıtım adaleti, kazanımların dağıtımında alınan kararlara ve bu kararların uygulanma aşamalarına bakmaksızın çalışanların aldıkları ödülleri hak edip etmediklerine yönelik algılarına odaklanır (Konovsky, 2000).

Etkileşimsel adalet, örgütsel işlemlerin informal yönü olarak yönetim ile çalışanlar arasındaki kişilerarası iletişimdeki adalet algısını vurgulamaktadır (Beugre, 2003). Bies'a (2001) göre çalışanlar sadece ödüllerin kimlere hangi kriterlere göre verildiğiyle ilgilenmezler, bunun yanında yöneticilerin nazik, dürüst ve saygılı olup olmamalarını içeren tutum ve davranışlarının niteliğiyle de ilgilenmektedirler. Yani çalışanların algıları neyin nasıl yapıldığından da etkilenmektedir (Brockner, Higgins ve Low, 2004). Adil bir etkileşim, yöneticilerin her bir çalışanla empatik bir iletişim kurarak onları dinlemesini, kararla ilgili açıklamalarda bulunmasını ve çalışanın istek ve beklentilerine karşı duyarlı olmasını gerektirmektedir.

\section{Okul yönetiminde kayırmacılık ve örgütsel adalet}

Yöneticilik görevinin temeli, örgüt içerisinde alınan kararlar, belirlenen amaçlar, kaynakların dağıtımı ve kullanımı ile kazanım ve değerlendirmeler noktasında çalışanlara karşı eşit, tarafsız ve adil olmaya dayanmaktadır (Aydın, 2002). Toplum içinde ve okul ortamında kişiler farklı haksızlıklara karşı demokrasi ile korunmaktadır, ancak toplumsal bir sistem olan okul iç ve dış baskı unsurları tarafından etkilenilmektedir (Şişman, Güleş ve Dönmez, 2010; Özcan, 2014). İç unsurlar okulu oluşturan ve okul yapısında yer alan memur, yönetici, öğretmen, müdür, yardımcı personel iken dış unsurlar yönetimde rol oynayan veliler ve bakanlık merkez örgütleridir (Bursalığlu, 2012). Bu baskı unsurları okul yönetiminin kayırmacı veya adaletsiz tutum ve davranışlar sergilemesinde etkili olmaktadır. Yöneticilerin görevlerini gerçekleştirirken aldıkları kararlar, uyguladıkları prosedür ve ilkeler ile insanlarla olan iletişim ve ilişkilerinde uzak durmaları gereken, ahlaka uygun olmayan davranışlar ile pek çok sebeplerle (sendika üyeliği, hemşericilik, siyasi görüş, aynı fakülteden mezuniyet durumu, akrabalık ilişkisi, cinsellik vb.) okul içinde bi- 
rey ya da grupları yasalara aykırı bir biçimde koruyup kollaması, desteklemesi, diğer personellere tanınmayan ayrıcalığı bu kişilere tanıyıp sunması kayırmacılık şeklinde ifade edilmektedir (Meriç, 2012). Kayırmacilı̆̆ örgütsel politika ve politik liderlik bağlamında değerlendiren Pounder ve Blase (1988) okullardaki kayırmacı tutum ve davranışlarının en çok yöneticilerin öğretmenler üzerindeki kontrol gücünü arttırma ve kendilerini koruma isteklerinden kaynaklandığını buna karşın kendini yetkin hisseden yöneticilerin ise kayırmacı eğilimlerde bulunmadığını iddia etmişlerdir. Konuyu eğitimin niteliği üzerinden inceleyen Coco ve Lagravinese (2014) ise okul yönetimindeki kayırmacı uygulamaların özellikle öğretmenlerin kendilerini geliştirme isteklerine ket vurarak eğitimin dolaylı maliyetlerini arttırdığını ifade etmişlerdir.

Jones (2004), yöneticilerin ahlaki eylemlerde bulunabilmeleri için herkese hitap eden ahlaki değerlere uygun kural ve esaslar belirlenmesi gerektiğini vurgulamaktadır. Yoksa yöneticiler davranışlarını kendilerine göre değerlendirip herhangi bir etik dışı davranışta bulunmadıklarını öne sürebilirler. Yöneticilerin okulun işleyişinde benimsedikleri tavır ve davranışlara göre şekillenen adalet faktörü okul yönetiminin olmazsa olmazıdır. Kibar ve saygılı olmak, ahlaki ilkelere uygun hareket etmek, eşit ve dengeli davranışlar sergilemek yöneticilerde bulunması gereken adalet unsurlarına örnek olarak gösterilebilir (Hoy ve Tarter, 2004). Ayrıca okuldaki yönetsel uygulama standartları ve kaynaklarını dağıtımı da okul örgütsel adaletin göstergeleri arasında sayılabilir. Bununla birlikte okul örgütünün tüm paydaşlarıyla bir bütünlük içerisinde olması için sağlıklı bir ikliminin oluşturulması, sağlıklı iklim için de öncelikle örgütsel adaletin sağlanması gerekmektedir (Rutter ve Maughen, 2002; Şişman ve Turan, 2004). Bu doğrultuda adaletsiz uygulamaların olduğu bir okulda çalışan öğretmenlerin mesleklerini icra etmekten aldıkları doyumların ve okullarına yönelik bağlılıkların azalması beklenmektedir (Cohen-Charash ve Spector, 2001; Greenberg ve Colquitt, 2005).

Örgüt ortamında sıklıkla kaynaklar dağıtılırken ortaya çıkan kayırmacı tutum ve davranışlar ile adalete bakış arasındaki ilişki örgütlerin geleceğini belirlemektedir. Şöyle ki, örgütler çalışanların ortaya koyduğu katkılarla başarıya ulaşırken kayırmacilık sorunu olan örgütlerde ortaya çkan adaletsizlik algısı örgütsel amaçalardan sapmalara sebep olmaktadır. Bu bağlamda çalışmada okul yönetiminde kullanılan kayırmacı uygulamalar ile öğretmenlerin örgütsel adalete yönelik algıları arasında öngörülen ilişkinin gerçekten var olup olmadığı, var ise yönü ve derecesinin ortaya konması amaçlanmıştır. 


\section{Yöntem}

\section{Evren ve Örneklem}

Öğretmenlerin, okul yöneticilerinin kayırmacı tutum ve davranışları ile örgütsel adalete ilişkin algıları arasındaki ilişkinin analiz edildiği bu çalışmanın evreni, 2016-2017 eğitim öğretim yılı güz döneminde, Afyonkarahisar ili merkez ilçesinde 1038'si sınıf ve 1026'sı branş öğretmeni olarak görev yapan 1078'i ilkokul ve 986'sı ortaokul öğretmeni olmak üzere toplam 2064 öğretmenden oluşturmaktadır. Örneklem basit seçkisiz örnekleme yöntemi ile belirlenmiş olup çalışmaya gönüllü katılmayı kabul eden 413 öğretmenden oluşmaktadır.

\section{Veri Toplama Araçları}

Örgütsel adalet ölçeği: Ölçek, Hoy ve Tarter (2004) tarafından geliştirilmiş, Taşdan ve Yilmaz (2008) tarafından Türkçeye uyarlanmıştır. Ölçek 5’li Likert tipinde tek faktör altında toplanan 10 ifadeden oluşmaktadır. Ölçekten elde edilen puanların yükselmesi örgütsel adalet konusunda olumlu yargıları ifade etmektedir. Orijinal ölçekteki maddelerin faktör yük değerleri .77'den yüksek ve ölçeğin açıkladığı varyans oranı \%78'dir. Güvenirlik katsayısı olarak belirlenen $\alpha$ değeri ise .97 'dir (Hoy ve Tarter, 2004). Taşdan ve Yllmaz (2008) tarafından uyarlanan versiyonda ise orijinal formdaki faktör yapısı korunarak açıkladığı varyans oranı \%61,74 olarak bulunmuştur. Maddelerin faktör yük değerleri .44 ile .89 arasında değişim gösterirken, güvenirlik katsayısı olarak belirlenen $\alpha$ değeri 92 olarak bulunmuştur. Bu çalışmada, ölçeğin mevcut faktör yapısı ile kullanılması tercih edilmiş olup güvenirlik analizi tekrar edilmiş ve güvenirlik katsayısı olarak belirlenen $\alpha$ değeri .90 olarak bulunmuştur.

Okul yönetiminde kayırmacılık ölçeği: Ölçek, Erdem ve Meriç (2012) tarafından geliştirilmiştir. Ölçek. planlama (4 ifade), değerlendirme (9 ifade), örgütleme ( 7 ifade) ve koordinasyon ( 5 ifade) olmak üzere 4 boyuttan ve 25 ifadeden oluşmaktadır. Ölçek toplam varyansın \% 73.06'sini açılamaktadır. Ölçeğin değerlendirme alt boyutu toplam varyansın \% 20.96'sini açılamakta ve faktör yük değerleri .42 ile .81 arasında değişmektedir. Koordinasyon alt boyutu 
toplam varyansın \% 20.57'sini açıklamakta ve faktör yük değerleri .65 ile .81 arasındadır. Örgütleme alt boyutu toplam varyansın \% 19.72'sini aç1klamakta ve faktör yük değerleri .58 ile .85 arasındadır. Planlama alt boyutu toplam varyansın \% 11.79'unu açıklamakta ve faktör yük değerleri .53 ile .78 arasındadır. Erdem ve Meriç (2012) ölçeğin güvenirlik katsayısı olarak belirlenen $\alpha$ değerini tüm ölçek için .96 , alt boyutlar için ise sirasiyla $.93, .92, .93, .83$ olarak bulmuştur. Bu çalışmada ölçeğe ilişkin faktör analizi yapılmamış, ölçeğin mevcut faktör yapısı kullanılmıştır. Güvenirlik analizi tekrar edilmiş ve $\alpha$ değeri ölçeğin tamamı için .95 , alt boyutlar için sırasıyla $.93, .91, .90$, .85 olarak bulunmuştur.

\section{Verilerin Analizi}

Çalışmada öğretmenlerin örgütsel adalet ve kayırmacılık algılarını belirlemek için ölçeklerden aldıkları ortalama puanlar ve standart sapmalar incelenmiştir. Öğretmenlerin örgütsel adalet algıları ile planlama, örgütleme, koordinasyon ve değerlendirme boyutlarındaki kayırmacilık algılarının branş, okul kademesi ve cinsiyet değişkenlerine göre farklılık gösterip göstermediğini incelemek için bağımsız örneklem t-testi, yaş ve kıdem değişkenlerine göre farklılık gösterip göstermediğini incelemek için ise tek yönlü varyans analizi kullanılmıştır. Tek yönlü varyans analizi sonrasında farklılığın belirlendiği durumlarda Post-Hoc testi olarak Levene testi 05'ten büyük çıttğ 1 durumlarda Tukey, küçük çıktığı durumlarda ise Games-Howell testi kullanılmıştır. Öğretmenlerin kayırmacılık algıları ile örgütsel adalet algıları arasında herhangi bir ilişkinin olup olmadığı korelasyon analizi ile incelenmiştir. Elde edilen veriler $\alpha=0.05$ anlamlılık düzeyinde analiz edilmiş ve bulgular çalışmanın amaçlarına uygun olarak tablolar halinde sunulmuştur.

\section{Bulgular}

\section{Katılımcılarn Demografik Özelliklerine İlişkin Bulgular}

Tablo 1'de çalışmaya katılan öğretmenlerin kıdem, yaş, cinsiyet, okul kademesi ve branş değişkenlerine göre frekans ve yüzde sonuçları verilmiştir. 
Tablo 1. Katılımcıların demografik değişkenlere göre dağılımı

\begin{tabular}{|c|c|c|c|}
\hline Demografik Değişkenler & Kategori & $\mathbf{N}$ & $\%$ \\
\hline \multirow{2}{*}{ Cinsiyet } & Kadın & 199 & 48.2 \\
\hline & Erkek & 214 & 51.8 \\
\hline \multirow{2}{*}{ Okul kademesi } & İlkokul & 131 & 31.7 \\
\hline & Ortaokul & 282 & 68.3 \\
\hline \multirow{2}{*}{ Branş } & Sınıf öğretmeni & 112 & 27.1 \\
\hline & Branş öğretmeni & 301 & 72.9 \\
\hline \multirow{3}{*}{ Yaş } & $22-30$ yaş & 127 & 30.8 \\
\hline & $31-40$ yaş & 177 & 42.9 \\
\hline & 41 ve üzeri & 109 & 26.4 \\
\hline \multirow{4}{*}{ Kıdem } & $1-5 \mathrm{y} 1 \mathrm{l}$ & 116 & 28.1 \\
\hline & 6-10 y1l & 105 & 25.4 \\
\hline & $11-15$ yıl & 74 & 17.9 \\
\hline & 16 yıl ve üzeri & 118 & 28.6 \\
\hline \multicolumn{2}{|c|}{ Toplam } & 413 & 100.0 \\
\hline
\end{tabular}

Tablo 1'e göre katılımclar cinsiyet değişkeni açısından ele alındığında, 214 kişinin erkek, 199 kişinin ise kadın olduğu tespit edilmiştir. Öğretmenler okul kademesi değişkeni açısından incelendiğinde; çoğunluğun 282 kişi ile ortaokul öğretmeni olduğu, 131 öğretmenin ise ilkokullarda görev yaptığı belirlenmiştir. Katılımcıların branş değişkenine göre dağılımına bakıldığında, 301'inin branş öğretmeni, 112'sinin ise sınıf öğretmeni olduğu saptanmıştır. Öğretmenlerin kıdemlerine bakıldığında; en fazla hizmet süresinin 118 kişi ile 16 yıl ve üzeri çalışanlara ait olduğu belirlenmiştir. Katılımcıların yaş gruplarına bakıldığında ise en fazla katılımcının 177 kişi ile 31-40 yaş grubuna ait olduğu görülmektedir.

\section{Katılımcıların Okul Yönetiminde Kayırmacılık Algılan İle Örgütsel Adalet Algılarına İlişkin Bulgular}

Öğretmenlerin, okul yönetiminde kayırmacılık algıları ile örgütsel adalet algılarına ilişkin ortalama puanları ve standart sapmaları tablo 2' de verilmiştir.

Tablo 2. Öğretmenlerin okul yönetimine ilişkin örgütsel adalet algılarının betimsel istatistikleri

\begin{tabular}{lccccc}
\hline Boyutlar & $\mathbf{N}$ & $\overline{\boldsymbol{X}}$ & ss. & Min. & Max. \\
\hline Örgütsel Adalet & 413 & 3.90 & .855 & 1.00 & 5.00 \\
Planlama alt boyutu & 413 & 1.98 & 1.107 & 1.00 & 5.00 \\
Örgütleme alt boyutu & 413 & 1.97 & 1.075 & 1.00 & 5.00 \\
Koordinasyon alt boyutu & 413 & 1.91 & 1.028 & 1.00 & 5.00 \\
Değerlendirme alt boyutu & 413 & 1.79 & .981 & 1.00 & 5.00 \\
\hline
\end{tabular}


Tablo 2'ye göre öğretmenlerin örgütsel adalet algılarının ortalaması 3.90, standart sapması .855'tir. Kayırmacilık algilarının ortalama ve standart sapmaları ise sırası ile plalama boyutu için 1.98, 1.107; örgütleme boyutu için 1.97, 1.075; koordinasyon boyutu için 1.91, 1.028 ve değerlendirme boyutu için $1.79, .981$ 'dir.

Puan skalası incelendiğinde örgütsel adalet algısının yüksek, kayırmacılık algisınn ise tüm alt boyutlarda düşük düzeyde olduğu görülmektedir. $\mathrm{Bu}$ bulguya dayanılarak okul yönetiminin kayırmacı tutum ve davranışlarda bulunmadığı ve okulda öğretmenlere adaletli davranıldığı öne sürülebilir.

Katılımcılarnn Demografik Özelliklerine Göre Okul Yönetiminde Kayırmacılık Algıları İle Örgütsel Adalet Algılarının Farklılaşmasına Yönelik Bulgular

Öğretmenlerin, okul yönetiminde kayırmacılık algıları ile örgütsel adalet algılarının cinsiyet değişkenine göre farklılık gösterip göstermediğini belirlemeye yönelik yapılan t-testi sonuçları tablo 3'de verilmiştir.

Tablo 3. Öğretmenlerin örgütsel adalet algıları ile okul yönetiminde yapılan kayırmacılığa ilişkin algılarmın cinsiyet değ̈işkenine göre farklılıkları

\begin{tabular}{|c|c|c|c|c|c|c|c|}
\hline Boyutlar & Cinsiyet & $\mathbf{N}$ & $\bar{X}$ & ss. & Sd & $T$ & $\mathbf{P}$ \\
\hline \multirow{2}{*}{ Örgütsel Adalet } & Kadın & 199 & 4.00 & .764 & \multirow{2}{*}{405} & \multirow{2}{*}{.36} & \multirow{2}{*}{.018} \\
\hline & Erkek & 214 & 3.80 & .925 & & & \\
\hline \multirow{2}{*}{ Planlama alt boyutu } & Kadin & 199 & 1.82 & 1.038 & \multirow{2}{*}{410} & \multirow{2}{*}{.74} & \multirow{2}{*}{.006} \\
\hline & Erkek & 214 & 2.12 & 1.152 & & & \\
\hline \multirow{2}{*}{ Örgütleme alt boyutu } & Kadın & 199 & 1.87 & 1.087 & \multirow{2}{*}{406} & \multirow{2}{*}{.77} & \multirow{2}{*}{.076} \\
\hline & Erkek & 214 & 2.06 & 1.058 & & & \\
\hline \multirow{2}{*}{ Koordinasyon alt boyutu } & Kadin & 199 & 1.85 & 1.015 & \multirow{2}{*}{410} & \multirow{2}{*}{.06} & \multirow{2}{*}{.288} \\
\hline & Erkek & 214 & 1.95 & 1.040 & & & \\
\hline \multirow{2}{*}{ Değerlendirme alt boyutu } & Kadın & 199 & 1.65 & .906 & \multirow{2}{*}{409} & \multirow{2}{*}{.61} & \multirow{2}{*}{.009} \\
\hline & Erkek & 214 & 1.90 & 1.034 & & & \\
\hline
\end{tabular}

${ }^{*} p<.05$

Tablo 3'e bakıldığında, örgütsel adalet ile kayırmacılığın planlama ve değerlendirme alt boyutlarında cinsiyet değişkenine göre istatistiksel olarak anlamlı farklılıklar görülürken, kayırmacılığın örgütleme ve koordinasyon alt boyutlarında cinsiyet değişkenine göre istatistiksel olarak anlamlı farklılıklar görülmemektedir. Bu bulgu, kadın öğretmenlerle erkek öğretmenlerin okul 
yöneticilerinin örgütleme ve koordinasyon alt boyutlarındaki uygulamalarında kayırmacılık yapıp yapmadıkları konusundaki düşüncelerinin birbirine yakın olduğunu ifade etmekle birlikte, öğretmenlerin örgütsel adalet algıları ile planlama ve değerlendirme aşamalarındaki kayırmacılık algılarının birbirinden farklı olduğunu ortaya koymaktadır. Yani kadın öğretmenlerin okul yönetimini daha adaletli olarak algıladıklarını buna karşın erkek öğretmenlerin okul yönetimini planlama ve değerlendirme alt boyutlarında daha kayırmacı olarak gördüklerini göstermektedir.

Çalışmaya katılan öğretmenlerin, okul yönetiminde kayırmacılık algıları ile örgütsel adalet algılarının okul kademesi değişkenine göre farklılık gösterip göstermediğini belirlemeye yönelik yapılan t-testi sonuçları tablo 4 'da verilmiştir.

Tablo 4. Öğretmenlerin örgütsel adalet algıları ile okul yönetiminde yapılan kayırmacılı̆̆a ilişkin algılarının okul kademesi değişkenine göre farklılıkları

\begin{tabular}{|c|c|c|c|c|c|c|c|}
\hline Boyutlar & Okul Kademesi & $\mathbf{N}$ & $\bar{X}$ & ss. & Sd & $\mathrm{T}$ & $\mathbf{P}$ \\
\hline \multirow{2}{*}{ Örgütsel Adalet } & İlkokul & 131 & 4.01 & .882 & \multirow{2}{*}{242.741} & \multirow{2}{*}{1.796} & \multirow{2}{*}{.074} \\
\hline & Ortaokul & 282 & 3.84 & .840 & & & \\
\hline \multirow{2}{*}{ Planlama alt boyutu } & İlkokul & 131 & 1.98 & 1.215 & \multirow{2}{*}{411} & \multirow{2}{*}{.005} & \multirow{2}{*}{.996} \\
\hline & Ortaokul & 282 & 1.98 & 1.056 & & & \\
\hline \multirow{2}{*}{ Örgütleme alt boyutu } & İlkokul & 131 & 2.00 & 1.251 & \multirow{2}{*}{207.652} & \multirow{2}{*}{.390} & \multirow{2}{*}{.697} \\
\hline & Ortaokul & 282 & 1.95 & .985 & & & \\
\hline \multirow{2}{*}{ Koordinasyon alt boyutu } & İlkokul & 131 & 1.98 & 1.196 & \multirow{2}{*}{207.662} & \multirow{2}{*}{.960} & \multirow{2}{*}{.338} \\
\hline & Ortaokul & 282 & 1.87 & .941 & & & \\
\hline \multirow{2}{*}{ Değerlendirme alt boyutu } & İlkokul & 131 & 1.90 & 1.164 & \multirow{2}{*}{201.824} & \multirow{2}{*}{1.429} & \multirow{2}{*}{.155} \\
\hline & Ortaokul & 282 & 1.73 & .882 & & & \\
\hline
\end{tabular}

${ }^{*} p<.05$

Tablo 4 incelendiğinde yapılan ikili karşılaştırmalar ve sıra ortalamaları incelendiğinde, örgütsel adalet ile kayırmacılığın tüm alt boyutlarında okul kademesi değişkenine göre öğretmenlerin algıları arasında istatistiksel olarak anlamlı farklılıklar bulunmadığı görülmektedir. Bu bulguya göre öğretmenlerin görev yaptıkları kademe, onların okul yöneticilerinin uygulamalarında kayırmaclık yapıp yapmadıklarına veya adaletli davranıp davranmadıklarına ilişkin algılarını değiştirmemektedir.

Öğretmenlerin, okul yönetiminde kayırmacılık algıları ile örgütsel adalet algılarının branş değişkenine göre farklılık gösterip göstermediğini belirlemeye yönelik yapılan t-testi sonuçları tablo 5'de verilmiştir. 
Tablo 5. Öğretmenlerin örgütsel adalet algıları ile okul yönetiminde yapılan kayırmacılığa ilişkin algılarının branş değişkenine göre farklılıkları

\begin{tabular}{|c|c|c|c|c|c|c|c|}
\hline Boyutlar & Branş & $\mathbf{N}$ & $\bar{X}$ & ss. & Sd & $\mathrm{T}$ & $\mathbf{P}$ \\
\hline \multirow{2}{*}{ Örgütsel Adalet } & Sınıf Öğretmeni & 112 & 4.03 & .872 & \multirow{2}{*}{193.560} & \multirow{2}{*}{1.821} & \multirow{2}{*}{.070} \\
\hline & Branş Öğretmeni & 301 & 3.85 & .846 & & & \\
\hline \multirow{2}{*}{ Planlama alt boyutu } & Sınıf Öğretmeni & 112 & 1.96 & 1.195 & \multirow{2}{*}{181.728} & \multirow{2}{*}{-.241} & \multirow{2}{*}{.810} \\
\hline & Branş Öğretmeni & 301 & 1.99 & 1.075 & & & \\
\hline \multirow{2}{*}{ Örgütleme alt boyutu } & Sınıf Öğretmeni & 112 & 2.02 & 1.269 & \multirow{2}{*}{411} & \multirow{2}{*}{.534} & \multirow{2}{*}{.594} \\
\hline & Branş Öğretmeni & 301 & 1.95 & .996 & & & \\
\hline \multirow{2}{*}{ Koordinasyon alt boyutu } & Sınıf Öğretmeni & 112 & 1.99 & 1.219 & \multirow{2}{*}{411} & \multirow{2}{*}{.991} & \multirow{2}{*}{.322} \\
\hline & Branş Öğretmeni & 301 & 1.88 & .948 & & & \\
\hline \multirow{2}{*}{ Değerlendirme alt boyutu } & Sınıf Öğretmeni & 112 & 1.90 & 1.163 & \multirow{2}{*}{411} & \multirow{2}{*}{1.350} & \multirow[b]{2}{*}{.178} \\
\hline & Branş Öğretmeni & 301 & 1.75 & .904 & & & \\
\hline
\end{tabular}

${ }^{*} p<.05$

Tablo 5'e göre, örgütsel adalet ile kayırmacılığın tüm alt boyutlarında branş değişkenine göre istatistiksel olarak anlamlı farklılıklar bulunmamaktadır. Bu bulgu ya göre sınıf ve branş öğretmenleri, okul yöneticilerinin öğretmenlere karşı adaletli davranıp davranmamaları ile uygulamalarında kayırmacilık yapıp yapmamaları konusunda hemfikirdirler.

Öğretmenlerin, okul yönetiminde kayırmacılık algıları ile örgütsel adalet algılarının yaş değişkenine göre farklılık gösterip göstermediğini belirlemeye yönelik yapılan tek yönlü varyans analizi testi sonuçları tablo $6^{\prime} \mathrm{da}$ verilmiştir.

Tablo 6'ya bakıldığında, öğretmenlerin örgütsel adalet algılarında istatistiksel olarak anlamlı bir farklılık olmamasına rağmen kayırmacılığın tüm alt boyutlarında gruplar arasında anlamlı farklılıklar olduğu görülmektedir. $\mathrm{Bu}$ bulgu, örgütsel adalete ilişkin algıların yaş değişkenine göre farklılaşmadığını buna karşın okul yöneticilerinin kayırmacı tutum veya davranışlarına ilişkin öğretmen algılarının yaş değişkenine göre tüm alt boyutlarda farkl1laştığını ifade etmektedir. Farklılığın hangi gruplar arasında olduğunu belirlemek için yapılan Games-Howell testine göre ise tüm alt boyutlarda genç öğretmenlerin puanlarının orta-yaşlı ve yaşlı öğretmenlerden anlamlı derecede düşük olduğu bulgulanmıştır. Buna göre genç öğretmenlerin planlama, örgütleme, koordinasyon ve değerlendirme boyutlarında orta-yaşlı ve yaşlı öğretmenlere göre yöneticilerini daha az kayırmacı algıladıkları söylenebilir. 
Tablo 6. Öğretmenlerin örgütsel adalet algıları ile okul yönetiminde yapılan kayırmacılı̆̆a ilişkin algılarının yaş değişkenine göre farklılıkları

\begin{tabular}{|c|c|c|c|c|c|c|c|}
\hline Boyutlar & Yaş & $\mathbf{N}$ & $\overline{\boldsymbol{X}}$ & ss. & $\mathbf{F}$ & $\mathrm{p}$ & Fark \\
\hline \multirow{3}{*}{ Örgütsel Adalet } & 1) $22-30$ & 127 & 3.99 & 0.800 & \multirow{3}{*}{1.624} & \multirow{3}{*}{.198} & \multirow{3}{*}{ Yok } \\
\hline & 2) $31-40$ & 177 & 3.81 & 0.890 & & & \\
\hline & 3) 41 ve üzeri & 109 & 3.93 & 0.857 & & & \\
\hline \multirow{3}{*}{ Planlama alt boyutu } & 1) $22-30$ & 127 & 1.66 & .898 & \multirow{3}{*}{10.171} & \multirow{3}{*}{.000} & \multirow{3}{*}{$\begin{array}{l}1<3 \\
1<2\end{array}$} \\
\hline & 2) $31-40$ & 177 & 2.03 & 1.113 & & & \\
\hline & 3) 41 ve üzeri & 109 & 2.29 & 1.224 & & & \\
\hline \multirow{3}{*}{ Örgütleme alt boyutu } & 1) $22-30$ & 127 & 1.72 & .887 & \multirow{3}{*}{7.324} & \multirow{3}{*}{.001} & \multirow{3}{*}{$\begin{array}{l}1<3 \\
1<2\end{array}$} \\
\hline & 2) $31-40$ & 177 & 1.98 & 1.060 & & & \\
\hline & 3) 41 ve üzeri & 109 & 2.25 & 1.228 & & & \\
\hline \multirow{3}{*}{ Koordinasyon alt boyutu } & 1) $22-30$ & 127 & 1.64 & .853 & \multirow{3}{*}{7.684} & \multirow{3}{*}{.001} & \multirow{3}{*}{$\begin{array}{l}1<3 \\
1<2\end{array}$} \\
\hline & 2) $31-40$ & 177 & 1.95 & 1.021 & & & \\
\hline & 3) 41 ve üzeri & 109 & 2.15 & 1.158 & & & \\
\hline \multirow{3}{*}{ Değerlendirme alt boyutu } & 1) $22-30$ & 127 & 1.54 & .741 & \multirow{3}{*}{7.759} & \multirow{3}{*}{.000} & \multirow{3}{*}{$\begin{array}{l}1<3 \\
1<2\end{array}$} \\
\hline & 2) $31-40$ & 177 & 1.82 & .986 & & & \\
\hline & 3) 41 ve üzeri & 109 & 2.03 & 1.148 & & & \\
\hline
\end{tabular}

${ }^{*} \mathrm{p}<.05$

Çalışmaya katılan öğretmenlerin, okul yönetiminde kayırmacılık algıları ile örgütsel adalet algılarının kıdem değişkenine göre farklılık gösterip göstermediğini belirlemeye yönelik yapılan tek yönlü varyans analizi testi sonuçları tablo 7'de verilmiştir.

Tablo 7'ye göre, öğretmenlerin örgütsel adalet algılarında istatistiksel olarak anlamlı bir farklılık olmamasına rağmen kayırmacılığın tüm alt boyutlarında gruplar arasında anlamlı farklılıklar olduğu görülmüştür. Bu bulgu, örgütsel adalete ilişkin algıların kıdem değişkenine göre farklılaşmadığını buna karşın okul yöneticilerinin kayırmacı tutum veya davranışlarına ilişkin alg1larının kıdem değişkenine göre tüm alt boyutlarda farklılaştığını göstermektedir. Farklılığın hangi gruplar arasında olduğunu belirlemek için yapılan Games-Howell testine göre ise tüm alt boyutlarda göreve yeni başlayan öğretmenlerin puanlarının daha kıdemli olan öğretmenlerden anlamlı derecede düşük olduğu bulgulanmıştır. Yani mesleğinin ilk yıllarındaki öğretmenler planlama, örgütleme, koordinasyon ve değerlendirme boyutlarında kendilerinden daha tecrübeli öğretmenlere göre yöneticilerini daha az kayırmacı algilamaktadırlar. 
Tablo 7. Öğretmenlerin örgütsel adalet algıları ile okul yönetiminde yapılan kayırmacılığa ilişkin algılarının kıdem değişkenine göre farklılıkları

\begin{tabular}{|c|c|c|c|c|c|c|c|}
\hline Boyutlar & K1dem & $\mathbf{N}$ & $\bar{X}$ & ss. & $\mathbf{F}$ & $\mathrm{p}$ & Fark \\
\hline \multirow{4}{*}{ Örgütsel Adalet } & 1) 1 - 5 yil & 116 & 3.93 & 1.916 & \multirow{4}{*}{.099} & \multirow{4}{*}{.961} & \multirow{4}{*}{ Yok } \\
\hline & 2) 6 - 10 yıl & 105 & 3.88 & 0.894 & & & \\
\hline & 3) 11 - $15 \mathrm{y} 1 \mathrm{l}$ & 74 & 3.87 & 0.664 & & & \\
\hline & 4) 16 yıl ve üzeri & 118 & 3.89 & 0.876 & & & \\
\hline \multirow{4}{*}{ Planlama alt boyutu } & 1) 1 - 5 yil & 116 & 1.73 & 0.969 & \multirow{4}{*}{3.758} & \multirow{4}{*}{.011} & \multirow{4}{*}{$1<4$} \\
\hline & 2) 6 - 10 yıl & 105 & 1.94 & 1.021 & & & \\
\hline & 3) 11 - $15 \mathrm{y} 1 \mathrm{l}$ & 74 & 2.09 & 1.131 & & & \\
\hline & 4) 16 yıl ve üzeri & 118 & 2.20 & 1.247 & & & \\
\hline \multirow{4}{*}{ Örgütleme alt boyutu } & 1) 1 - 5 yil & 116 & 1.70 & 0.884 & \multirow{4}{*}{5.307} & \multirow{4}{*}{.001} & \multirow{4}{*}{$\begin{array}{l}1<3 \\
1<4\end{array}$} \\
\hline & 2) 6 - $10 \mathrm{yll}$ & 105 & 1.89 & 0.993 & & & \\
\hline & 3) 11 - $15 \mathrm{y} 1 \mathrm{l}$ & 74 & 2.12 & 1.112 & & & \\
\hline & 4) 16 yıl ve üzeri & 118 & 2.21 & 1.227 & & & \\
\hline \multirow{4}{*}{ Koordinasyon alt boyutu } & 1) 1 - 5 y1l & 116 & 1.69 & 0.891 & \multirow{4}{*}{4.165} & \multirow{4}{*}{.006} & \multirow{4}{*}{$\begin{array}{l}1<3 \\
1<4\end{array}$} \\
\hline & 2) 6 - 10 y1l & 105 & 1.81 & 0.967 & & & \\
\hline & 3) 11 - 15 y1l & 74 & 2.13 & 1.070 & & & \\
\hline & 4) 16 yıl ve üzeri & 118 & 2.07 & 1.136 & & & \\
\hline \multirow{4}{*}{ Değerlendirme alt boyutu } & 1) 1 - 5 yil & 116 & 1.60 & 0.830 & \multirow{4}{*}{3.370} & \multirow{4}{*}{.019} & \multirow{4}{*}{$1<4$} \\
\hline & 2) 6 - 10 y1l & 105 & 1.72 & 0.892 & & & \\
\hline & 3) 11 - 15 y1l & 74 & 1.89 & 1.065 & & & \\
\hline & 4) 16 yıl ve üzeri & 118 & 1.98 & 1.105 & & & \\
\hline
\end{tabular}

${ }^{*} \mathrm{p}<.05$

Katılımcılarn Okul Yönetiminde Kayırmacılık Algıları İle Örgütsel Adalet Algıları Arasındaki İlişkilere Dair Bulgular

Öğretmenlerin, okul yöneticilerinin kayırmacı tutum ve davranışlarına ilişkin algıları ile örgütsel adalet algıları arasındaki ilişkinin test edilmesi için yapılan korelasyon analizi sonuçları tablo 8'de verilmiştir.

Tablo 8. Örgütsel adalet ve kayırmacılı̆̆ın alt boyutlarna ilişkin korelasyon değerleri

\begin{tabular}{cccccc}
\hline \multirow{2}{*}{ Boyutlar } & & $\begin{array}{c}\text { Planlama } \\
\text { alt boyutu }\end{array}$ & $\begin{array}{c}\text { Örgütleme } \\
\text { alt boyutu }\end{array}$ & $\begin{array}{c}\text { Koordinasyon } \\
\text { alt boyutu }\end{array}$ & $\begin{array}{c}\text { Değerlendirme } \\
\text { alt boyutu }\end{array}$ \\
\hline \multirow{3}{*}{ Örgütsel Adalet } & $\mathbf{r}$ & $-.311^{* *}$ & $-.346^{* *}$ & $-.359^{* *}$ & $-.365^{* *}$ \\
\cline { 2 - 6 } & $\mathbf{p}$ & .000 & .000 & .000 & .000 \\
\cline { 2 - 6 } & $\mathbf{N}$ & 413 & 413 & 413 & 413 \\
\hline
\end{tabular}

${ }^{*} . \mathrm{p}<.05{ }^{* *} \mathrm{p}<.01$ 
Tablo 8'e göre çalışmaya katılan öğretmenlerin, okul yöneticilerinin kayırmacı tutum ve davranışlarına ilişkin algıları ile örgütsel adalet algıları arasındaki ilişki incelendiğinde, okul yönetiminde kayırmacılığın tüm alt boyutları ile örgütsel adalet arasında negatif yönlü düşük düzeyde fakat anlamlı bir ilişki olduğu görülmektedir. Bu bulguya dayanarak okul yönetiminin planlama, örgütleme, koordinasyon ve değerlendirme alt boyutlarındaki kayırmacı tutum ve davranışlarını gösterme sıklığı azaldıkça öğretmenlerin okul yönetimine duydukları örgütsel güvende göreceli olarak az ama manidar bir artış olacağı öne sürülebilir.

\section{Sonuç ve Tartışma}

Bu çalışmada, öğretmenlerin okul yöneticilerinin uygulama veya davranışlarına yönelik kayırmacılık ve örgütsel adalet algıları arasındaki ilişkinin belirlenmesi amaçlanmıştır. Çalışma kapsamında ilk olarak, öğretmenlerin okul yönetiminde kayırmacılığa ve örgütsel adalete ilişkin görüşleri incelenmiş, ardından öğretmenlerin görüşlerinin demografik değişkenlere göre farklılık gösterip göstermediğine bakılmıştır. Son olarak da öğretmenlerin okul yönetiminde kayırmacılık algıları ile örgütsel adalet algıları arasındaki ilişki ortaya konulmuştur.

Çalışma sonucunda öğretmenlerin okul yönetimine yönelik düşük düzeyde kayırmacılık algısına sahip oldukları bulunmuştur. Ancak, çeşitli kayırmacılık türlerine ilişkin alanyazında yer alan benzer çalışmalar incelendiğinde öğretmenlerin okul yönetiminde kayırmacı uygulamalara yönelik alg1larının farklı düzeylerde olduğu sonucuna ulaşılmaktadır. Polat ve Kazak (2014), ilk ve ortaöğretim kurumlarında gerçekleştirdikleri çalışmada öğretmenlerin okul yöneticilerinin kayırmacılığına ilişkin görüşlerinin düşük düzeyde olduğunu belirlerken, Argon (2016) ilkokul öğretmenlerinin okul yönetiminde kayırmacilık algılarının yüksek düzeyde olduğunu tespit etmiştir. Meriç ve Erdem (2013), öğretmen algılarına göre okul yöneticilerinin planlama, örgütleme, koordinasyon ve değerlendirme boyutlarındaki faaliyetlerinde çok ender kayırmacılık yaptıkları sonucuna ulaşırken, Aydın (2015) çalışmasında okul yöneticilerinin düşük düzeyde kayırmacı tutum ve davranış sergilediklerini ifade etmiştir. Alanyazındaki çalışma bulgularında yer alan kayırmacılığa ilişkin algı düzeylerinde görülen bu farklılığın öncelikle kulla- 
nılan veri toplama araçları ve verilerin toplandığı okulların kültürü ve ikliminin birbirlerinden farklı olmasından kaynaklandığı düşünülmektedir. Bir diğer sebep olarak da okul yöneticilerinin kişisel özelliklerinin de bu farklılaşmada etkili olabileceği ön görülmektedir.

Çalışmanın diğer sonuçları incelenecek olursa; öğretmenlerin okul yönetiminde kayırmacılık algılarının cinsiyet değişkenine göre planlama ve değerlendirme alt boyutlarında istatistiksel olarak anlamlı bir şekilde farklılaştığı, örgütleme ve koordinasyon alt boyutlarında ise farklılaşmadığı belirlenmiştir. Alanyazında yer alan çalışmalara bakıldığında öğretmenlerin okul yönetiminde yönelik kayırmacılık algıları ile ilgili olarak cinsiyet değişkenine göre farklı sonuçların ortaya çıktığı görülmektedir. Aydın (2015), çalışmasinda kayırmacılığın tüm alt boyutlarında öğretmen algılarının cinsiyete göre değişmediğini belirtmiştir. Demirbilek (2018) ise öğretmenlerin okul yöneticilerinin kayırmacılık türlerinden yalnızca kronizme yönelik uygulamalarına ilişkin algılarının cinsiyete göre farklılaşmadığını, ancak kadın öğretmenlerin erkek öğretmenlere oranla okul müdürünün eş, dost ve arkadaşlarını daha çok kayırdığını düşündükleri sonucuna ulaşmıştır. Kadın öğretmenlerin, erkek öğretmenlere nazaran okul yöneticilerini daha kayırmacı algıladıklarını belirleyen Meriç ve Erdem'in (2013) çalışması da bu çalışmanın sonuçlarını doğrular niteliktedir. Bu durumun okul yöneticilerinin büyük bölümünün erkeklerden oluşması ve yöneticilerin kadın öğretmenlere oranla erkek öğretmenlerle daha güçlü iletişim kurmaları sebebiyle erkek öğretmenlerin okul yöneticilerinin davranış ve uygulamalarını daha adil bulmalarından kaynakladığı düşünülmektedir. Öğretmenlerin okul yönetiminde kayırmacilık alg1ları okul kademesi ve branş değişkenine göre incelendiğinde çalışılan kademenin (ilkokul/ortaokul) veya branşın (sınıf öğretmeni/alan öğretmeni) öğretmenlerin kayırmacılık algılarını farklılaştırmadığı bulunmuştur. Ayrıca, Meriç ve Erdem (2013), Aydın (2015) ve Demirbilek'in (2018) çalışmalarındaki bulgular da bu çalışma sonuçlarını doğrulamaktadır. Buna karşın, öğretmenlerin okul yönetiminde kayırmacılık algıları yaş ve kıdem değişkenlarine göre karşılaştırıldığında, kayırmacılığın tüm alt boyutlarında istatistiksel olarak anlamlı farklılıklar olmakla beraber özellikle mesleğe yeni başlayan genç öğretmenlerin okul yönetimine yönelik kayırmacılık algılarının yaşça büyük ve daha fazla tecrübeye sahip öğretmenlerden düşük olduğu sonucuna varılmıştır. Bu duruma öğretmenlerin ilerleyen meslek hayatlarıyla bir- 
likte şahit oldukları kayırmacı tutum veya olayların algılarındaki olumsuzluğu zamanla arttırarak pekiştirmesinin sebep olduğu düşünülmektedir. Alanyazında bu konuda farklı görüşlere ve bulgulara rastlanmaktadır; Aydın (2015) öğretmenlerin okul yönetiminde planlama aşamasında yapılan kayırmacılık algılarında mesleki kıdeme göre istatistiksel olarak anlamlı farklılık bulunduğunu tespit etmiş, buna karşın Meriç ve Erdem (2013) ile Demirbilek (2018) öğretmenlerin okul yönetiminde kayırmacı uygulamalara ilişkin görüşlerinin yaş ve kıdem değişkenlerine göre değişmediğini ifade etmişlerdir. Aydoğan (2009), hizmet süreleri 16-25 yıl arası olan öğretmenlerin okul yönetiminde kayırmacı tutum ve davranışlara ilişkin algilarının yüksek, 0-15 yıl ile 26-üstü yıl hizmet süresine sahip öğretmenlerde ise yüksek çıktığını ortaya koymuştur.

Çalışmanın bir diğer önemli sonucu olarak Polat (2007), Çırak (2013) ve Dündar (2011) çalı̧̧malarında olduğu gibi bu çalışmada da öğretmenlerin örgütsel adalet algıları yüksek bulunmuştur. Bu sonucun ortaya çıkmasında okulların yapısal özelliklerinden biçimselleşmenin etkili olduğu düşünülmektedir. Biçimselleşmenin altında yatan temel amaç, çalışanların iş davranışlarını öngörme ve kontrol etmedir (Daft, 2010). Çalışanların görevlerini yerine getirmelerine ilişkin bilgiler, ayrıntılı bir şekilde belirtilmiş ve bunlar yazıyla ifade edilip, belgelenmişse; hangi işi kimin, nasıl yapacağı ve karşıllğında ne alacağı üzerine belirsizlikler azalacaktır. Bu da çalışanların adaletsizlik algılarını düşürecektir. Yani okulların örgütsel yapıları biçimselleştikçe öğretmenlerin örgütsel adalet algılarının da yükselmesi beklenmektedir. Ayrıca, Türk Milli Eğitim sistemi de merkezi olmasından dolayı son derece biçimsel bir yapıya sahiptir.

Öğretmenlerin örgütsel adalet algıları cinsiyet değişkenine göre karşılaştırıldığında alanyazında çalışma sonuçlarıyla örtüşen ve örtüşmeyen bulgular yer almaktadır. Bu çalışmada öğretmenlerin örgütsel adalet algılarının kadınlar lehine istatistiksel olarak anlamlı bir şekilde farklılaştı̆̆ belirlenmesine rağmen, Polat ve Celep (2008), Çırak (2013) ile Demirbilek'in (2018) öğretmenlerin örgütsel adalet algılarının erkek öğretmenler lehine farklılık gösterdiği, Dündar (2011) ise cinsiyet değişkenin öğretmenlerin örgütsel adalet algılarında her hangi bir farklılık yaratmadığı sonucuna ulaşmıştır. Alanyazındaki bulguların örtüşmeme nedeninin tıpkı kayırmacılı̆̆ın cinsiyet değişkenine göre incelenmesinde olduğu gibi örneklem gruplarının görev yaptıkları okullardaki uygulama farklılıklarından, yöneticilerin kişisel özelliklerinden 
ve kullanılan farklı örgütsel adalet ölçeklerinden kaynaklandığı ileri sürülebilir. Öğretmenlerin örgütsel adalet algıları okul kademesi ve branş değişkenlerine göre karşılaştıılldığında, öğretmenlerin örgütsel adalet algılarının istatistiksel olarak anlamlı bir şekilde farklılaşmadığı belirlenmiştir. Alanyazın incelendiğinde, okul kademesi değişkenine göre öğretmenlerin örgütsel adalet algılarına ilişkin farklı bulgulara ulaşıldığı görülmektedir. Demirbilek (2018), öğretmenlerin örgütsel adalet algılarının okul kademesi ve branşa göre istatistiksel olarak anlamlı farklılık gösterdiğini ortaya koymuşlardır. Polat ve Celep (2008) ile Çırak (2013) ise öğretmenlerin örgütsel adalet algılarının okul kademesi ve branş değişkenlerinden etkilenmediğini belirlemiştir. Ortaya çıkan bu farklılıkların öğretmenlere sağlanan imkânların okul kademesine göre değişmesinden ve çalışmaların yapıldığı örgütlerin, kendi örgütsel özellikleriyle ilgili farklı değişkenlerden (örgüt iklimi, iletişim, vb.) kaynaklandığı düşünülmektedir. Öğretmenlerin örgütsel adalet algıları yaş ve kıdem değişkenlerine göre karşılaştırıldığında ise öğretmenlerin örgütsel adalet algılarının istatistiksel olarak anlamlı bir şekilde farklılaşmadığı belirlenmiştir. Çırak (2013) ve Demirbilek (2018) çalışma bulgularına benzer şekilde öğretmenlerin yaş ve kıdem değişkenlerine göre örgütsel adalet algılarında farklılaşma olmadığını saptamıştır. Buradan yola çıkarak farklı yaş ve kıdemdeki öğretmenlerin benzer düzeyde örgütsel adalet algısına sahip olduğu söylenebilir.

Çalışmada, öğretmenlerin okul yönetiminde planlama, örgütleme, koordinasyon ve değerlendirme aşamalarında kayırmacılık yapıldığına dair alg1ları arttığında, örgütsel adalet algıların da nispeten azaldığı görülmüştür. Polat ve Kazak (2014) çalışmalarında ilköğretim okullarında eğitim veren öğretmenlerin okul yöneticilerine yönelik kayırmacı davranış ve tutumları ile örgütsel adalet algıları arasında negatif ama anlamlı bir ilişki tespit ederek kayırmacilığın örgütsel adaletin anlamlı bir yordayıcısı olduğu sonucuna varmışlardır. Benzer bir sonuca Argon'un (2016) çalışmasında da rastlanılmaktadır; yöneticilerin okullarda cinsiyet, sendika, eş, dost, akraba, ödül-ceza, görevde yükselme ve kendi çıkarları gibi alanlarda kayırmacı davranışlar sergiledikleri; izin, nöbet çizelgesi, ders saatleri gibi durumlarda kayırmacilığı kendi menfaatleri için kullananların kendilerine, yöneticiye, örgüt kültürüne, okul iklimine yönelik olumsuz tutum geliştirdikleri görülmüştür. Benzer bir sonuçla Karacaoğlu ve Yörük (2012) tarafından aile işletmesi için yapılan çalışmada da karşılaşılmıştır. Adı geçen çalışmada, personellerin nepotizm ile 
örgütsel adalet algıları arasında düşük düzeyde ve negatif bir ilişkinin olduğu ayrıca çalışanların hem örgütsel adalet hem de nepotizm algılamalarının demografik değişkenlere göre farklılık göstermediği sonucuna varılmış, kayırmaclık alt boyutlarından terfide kayırmacılık ve işe alım sürecinde kayırmacilık boyutunun örgütsel adalet algısında etkili olduğu görülmüştür. Kayırmacılığın adaletsiz bir uygulama olmasından dolayı katılımcıların adalet algısını düşürmesi olağan görülmektedir. İncelenen çalışmalar örgütlerde görülen kayırmacı tutum ve davranışların bu çalışma sonucuyla aynı doğrultuda olduğunu göstermekte; çalışanlarda oluşan adaletsizlik algısının örgütsel bağlllık (Demirbilek, 2018) ve örgüt iklimine uyum (Polat ve Kazak, 2014) gibi süreçlerin tam olarak sağlanamaması ile iş stresinin (Karacaoğlu ve Yörük, 2012) ve tatminsizliğinin artması (Araslı ve Tümer, 2008) ve de çalışanlar arasında saldırgan davranışlar gözlenmesi (Özgan, 2011) gibi olumsuz sonuçlar doğurabileceğini kanıtlamaktadır. Ayrıca, uluslararası alanyazın incelendiğinde ulusal alanyazındaki bulguları doğrular bir şekilde örgütsel uygulamalara yönelik düşük adalet algısının çalışanların yöneticilerine güvenlerinin (Loi, Yang ve Diefendorf, 2009), örgütlerine bağlllıklarının (Akanbi ve Ofoegbu, 2013), performans (Bobocel ve Hafer, 2007) ve iş tatminlerinin (Cohen-Charash ve Spector, 2001) azalmasına sebep olmakla birlikte, çalışanlar arasındaki çatışmaları (Know, 2006) ve çalışanların işten ayrılma niyetlerini arttırdığı (Aryee, Budhwar ve Chen, 2002) görülmüştür. Benzer şekilde yöneticiler tarafından gösterilen kayırmacı tutum ve davranışlar da iş tatmininin ve performansin düşmesine (Abdalla, Maghrabi ve Raggad 1998), örgütsel bağlllık ve güvene yönelik olumsuz tutumlarının oluşmasına (Cremers, 2004) ve motivasyonun azalmasına (Chegini 2009) neden olmaktadır.

Bu çalışmanın sonuçları alan yazınla karşılaştırıldığında son söz olarak; öğretmenlerin okul yöneticileri tarafından bazı boyutlarda cinsiyet ve k1deme göre kayırmacılık yapıldığı algısı okul yöneticileriyle paylaşılabilir. Kayırmacılık ve örgütsel adalet ilişkisi bağlamında kayırmacılık algısının ortadan kaldırılması için de öncelikle yüksek bir adalet algısının okullarda oluşturulması gerekmektedir. Örgütsel adalet algısını güçlendirmek ve kayırmacllık algısını azaltmak için ise yönetişim ve hesapverbilirlik ilkeleri çerçevesinde öğretmenlerin de örgütsel karar alma süreçlerine dahil edilmesi, kaynakların kullanımı ve dağıtımının standart normlara tabi tutulması önerilebilir. Bundan sonra yapılacak çalışmalarda kayırmacılık ve örgütsel adalet arasında diğer örgütsel değişkenlerin aracllık etkisinin olup olmadığı veya 
bu iki değişkenin sinizm, mobbing, güven gibi değişkenlerle ilişkileri incelenebilir. Ayrıca konu farklı örneklemlerde veya farklı metodolojik yaklaşımlarla tekrar ele alınarak eğitim yönetimi alanyazının zenginleşmesine katkıda bulunulabilir. 
EXTENDED ABSTRACT

\title{
The Relationship Between Favoritism in School Management and Organizational Justice The Sample of Afyonkarahisar
}

\author{
Ayşe Cesur - Evrim Erol \\ Ministry of National Education- Dumlupinar University
}

Favoritism, generally defined as the tendency to deviate from the right and justice for the benefit of a person or a group (Erdem, 2010), can be described as the attitudes and behaviors of the school administrators such as supporting, protecting, defending and fronting for only those who are close, same or similar to themselves, by unethically deviating from the right and justice for their own benefits in their school work and procedures in school management using various means of moral influence such as friendship, kinship/intimacy, and similarity regardless of the individuals' competencies (merit) (Demirbilek, 2018). Organizational justice is the perception of justice around the individual (Greenberg, 1996). This perception of justice comes out during the fair distribution of punishments and rewards (Eren, 2010). In addition, the criteria used in the distribution of reward-punishment, promotion, and wages, how these criteria are determined and communicated to the employees are also the indicators of organizational justice (Karacaoğlu \& Yörük, 2012). Organizational justice is a term that covers employees' perceptions about how fairly they are treated within the organization and how the results of these perceptions affect the organization (Çöp, 2008). The extent of the relationship between the favoritist practices in organizations and the outlook on justice determines the future of organizations. Favoritism, which has become a very common phenomenon today, generally occurs when organizational outcomes are distributed among the employees. The favoritist attitudes and behaviors encountered in the organizations cause the perception of injustice. This situation also affects the organizational climate negatively, namely while organizations succeed with the contributions of the employees, the organizational spirit is damaged in teams with favoritism problems (Karacaoğlu \& Yö- 
rük, 2012). In this context, it is thought that the favoritist attitudes and behaviors, an unethical and unfair practice within the schools, will lead to inequality, and accordingly to the decrease in the teachers' perceptions of organizational justice.

In this study, it was aimed to determine the relationship between the teachers' perceptions of favoritism in school management and organizational justice.

The study was designed in the survey model. The sample of the study determined by a simple random sampling method has consisted of 413 teachers in the city center of Afyonkarahisar. The study data were collected through Organizational Justice Scale (Taşdan and Yılmaz, 2008) and Scale on Favoritism in School Management (Erdem and Meriç, 2012). In the study, t-test for comparisons, one-way variance analysis, Pearson Product Moment Correlation Coefficient, and descriptive statistics were used.

According to the findings obtained in the study; teachers have a high level of organizational justice perception and a low level of favoritism perception in school management. In the study, according to the demographic characteristics of teachers, it was stated that there were no significant differences in their perceptions of organizational justice except for gender variables (school type, branch, age, and seniority) while there were significant differences in their perceptions of favoritism in school management. Whereas the teachers' perceptions of organizational justice show statistically significant differences according to the gender variance, they don't show statistically significant differences according to the school type, branch, age, and seniority variances. In the study, it was found out that there were low-level, in the negative direction, significant relationships between the whole dimensions determining the teachers' perceptions of favoritism in school management and their perceptions of organizational justice.

As a result of the study, it has been found that teachers have a low level of favoritism towards school management. However, when similar studies in the literature related to the various types of favoritism are examined, it is concluded that teachers' perceptions of favoritist practices in school management are at different levels. It is considered that this difference in the perception levels of favoritism in the study findings in the literature is firstly due to the fact that the data collection tools used and the culture and climate of the 
schools where the data were collected are different from each other. As another reason, it is foreseen that the personal characteristics of the school administrators may be effective in this differentiation. As another important result of the study, it has been found that the teachers' perceptions of organizational justice are high. It is thought that the formalization levels of the schools in the Turkish National Education system, which has a central structure, are effective in the emergence of this result. When the relationship between the teachers' perceptions of favoritism in school management and their perceptions of organizational justice is examined, it is stated that there is a low-level, in the negative direction, the significant relationship between their perceptions of favoritism in school management and their perceptions of organizational justice. In other words, when the teachers' perceptions of favoritism in planning, organizing, coordination and evaluation stages in school management increase, their perceptions of organizational justice decrease relatively. In order to strengthen the perception of organizational justice and reduce the perception of organizational favoritism, it can be suggested that the teachers should be included in organizational resolution processes and the use and distribution of organizational resources should be put to standard norms in accordance with the principles of accountability and governance. In future studies, whether there is a mediating effect of other organizational variables between favoritism and organizational justice, or the relationship of these two variables with such variables as cynicism, mobbing, and trust. Besides, the subject can contribute to the enrichment of the educational management literature by being reconsidered in different samples or with different methodological approaches.

\section{Kaynakça / References}

Abdalla, F. H., Maghrabi, S. ve Raggad, G. B. (1998). Assessing the perceptions of human resources managers towards nepotism: A cross-cultural study. International Journal of Manpower, 19(8), 554- 570.

Akanbi, P. A. ve Ofoegbu, O. E. (2013). Impact of perceived organizational justice on organizational commitment of a food and beverage firm in Nigeria. International Journal Of Humanities And Social Science, 14, 207-218.

Aktan, C. C. (2001). Siyasal patoloji ve siyasal hastalklarm anatomisi (Tanı ve tedavi). Ankara: Hak-İş Yayınları. 
Andvig, J., Fjeldstad, O. H., Amundsen, I., Sissener, T. ve Soreide, T. (2001). Corruption a review of contemporary research. Norway: Michelsen Institute.

Arasl1, H. ve Tümer, M. (2008). Nepotism, favoritism and cronyism: A study of their effects on job stress and job satisfaction in the banking industry of North Cyprus. Social Behavior and Personality, 36(9), 1237-1250.

Argon, T. (2016). Öğretmen görüşlerine göre ilkokullarda yöneticilerin kayırmacılık davranışları. Kastamonu Ĕ̈itim Dergisi, 24(1), 233-250.

Aryee, S., Budhwar, P. S. ve Chen, Z. X. (2002). Trust as a Mediator of the Relationship Between Organizational Justice and Work Outcomes: Test of a Social Exchange Model. Journal of Organizational Behavior, 23(3), 267-285.

Aydın, İ. (2002). Yönetsel mesleki ve örgütsel etik (3. Bask1). Ankara: Pegem A Yayınlari.

Aydın, Y. (2015). Örgütsel sessizliğin okul yönetiminde kayırmacılık ve öğretmenlerin öz yeterlik algısı ile ilişkisi. Yayınlanmamış yüksek lisans tezi. Gazi Üniversitesi, Sosyal Bilimler Enstitüsü, Ankara.

Aydoğan, İ. (2009). Favoritism in the Turkish educational system: Nepotism, cronyism and patronage. Educational Policy Analysis and Strategic Research, 4(1), 19-35.

Aytaç, Ö. (2010). Yönetim ve örgüt açısından kayırmacılık. İstanbul: Beta Yayınları.

Beugre, C. D. (2003). Understanding organizational justice and its impact on managing employees: An African perspective. The International Journal of Human Resource Management, 13(7), 1091-1104.

Bies, R. J. (2001). International justice: The sacred and the profane. In J. Greenberg ve R. Cropanzano (Ed.). Advances in organization justice içinde (s. 89-118). Palo Alto, CA: Stanford University Press.

Bobocel, D. R. ve Hafer, C. L. (2007). Justice motive theory and the study of justice in work organizations: A conceptual integration. European Psychologist, $12,283-289$.

Brockner, J., Higgins, E. T. ve Low, M. B. (2004), Regulatory focus theory and the entrepreneurial process. Journal of Business Venturing, 19(2), 203-220.

Bursalığlu, Z. (2012). Okul yönetiminde yeni yapı ve davranış. Ankara: Pegem Yayınları.

Büte, M. (2011). Nepotizm ve iş tatmini ilişkisinde iş stresinin aracı rolü var mıdır. Dumlupınar Üniversitesi Sosyal Bilimler Fakültesi Dergisi, 29, 175-184.

Chegini, M. G. (2009). The relationship between organizational justice and organizational citizenship behavior. American Journal of Economics and Business Administration, 1(2), 173-176. 
Coco, G. ve Lagravinese, R. (2014). Cronyism and education performance. Economic modeling, 38, 443-450.

Cohen-Charash, Y. ve Spector, P. E. (2001). The role of justice in organizations: A meta-analysis. Organizational Behavior and Human Decision Processes, 86, 278-321.

Cohen, R. L. (1987). Distributive justice: Theory and research. Social Justice Research, 1(1), 19-40.

Cremers, D. (2004). Procedural and distributive justice effects moderated by organizational identification. Journal of Managerial Psychology, 20(1), 4-13.

Cropanzano, R. Bowen, D. E. ve Gilliland, S. W. (2007). The management of organizational justice. Academy of Management Perspectives, 21(4), 34-48.

Çırak, S. (2013), İlköğretim okulu öğretmenlerinin örgütsel adalet algısı. Yayınlanmamış yüksek lisans tezi. Hacettepe Üniversitesi, Sosyal Bilimler Enstitüsü, Ankara.

Çöp, S. (2008). Türkiye'de ve Polonya'da turizm sektörü çalı̧̧anlarmmin örgütsel adalet ve örgütsel bağlllik alg̨larına ilişkin bir uygulama. Yayınlanmamış yüksek lisans tezi. Gazi Üniversitesi, Eğitim Bilimleri Enstitüsü, Turizm İşletmeciliği Eğitimi Anabilim Dalı, Ankara.

Daft, R. L. (2010). Organization Theory and Design (10th edition.), St. Paul: West Publishing Co, USA.

Demirbilek, N. (2018). Okul müdürlerinin kayırmacı davranışlarının öğretmenlerin örgütsel adalet algıları ile müdüre güvene etkisi. Yayınlanmamış yüksek lisans tezi. İnönü Üniversitesi, Eğitim Bilimleri Enstitüsü, Malatya.

Dündar, T. (2011). Öğretmenlerin örgütsel adalet algıları ile iş doyumu düzeyleri arasindaki ilişki. Yayınlanmamış yüksek lisans tezi. Yıldız Teknik Üniversitesi, Sosyal Bilimler Enstitüsü, İstanbul.

Erdem, M. ve Meriç, E. (2012). Okul yönetiminde kayırmacıllğa ilişkin ölçek geliştirme çalışması. Eğitim Bilimleri Araştırmaları Dergisi, 2(2), 141-154.

Erdem, R. (2010). Kayırmacılık/ayrımcılık. R. Erdem (Ed.), Yönetim ve örgüt açısından kayırmacılık içinde (s. 10-45). İstanbul: Beta Yayınclık.

Greenberg, J. (1990). Organizational justice: Yesterday, today and tomorrow. Journal of Management, 16(2), 399-432.

Greenberg, J. (1996). The quest for justice on the job: Essays and experiments. Thousand Oaks, CA: Sage Publications.

Greenberg, J. ve Colquitt, J. A. (2005). Handbook of organizational justice. New Jersey: LEA 
Güven, H. S. (1976). İdare siyaset ilişkileri ve personel yönetimi. Amme İdaresi Dergisi, 9(1), 50-70.

Hoy, W. K. ve Tarter, C. J. (2004). Organizational justice in schools: No justice without trust. Journal of Educational Management, 18(4), 250-259.

İlhan, S. ve Aytaç, Ö. (2010). Türkiye'de kayırmacı eğilimlerin oluşmasında toplumsal ve kültürel yapının rolü. R. Erdem (Ed.), Yönetim ve örgüt açısından kayırmacılık içinde (s. 61-83). İstanbul: Beta Yayıncılık.

Jones, D. A. (2004). Counterproductive work behavior toward supervisors and organizations: Injustice, revenge, and context. Best paper pro-ceedings of the 64th annual meeting of the academy of management içinde (s. 85-117) Birmingham, AL: Academy of Management.

Karacaoğlu, K. ve Yörük, D. (2012). Çalışanların nepotizm ve örgütsel adalet algılamaları: Orta Anadolu bölgesinde bir aile işletmesi uygulaması. İş, Güç, Endüstri İlişkileri ve Insan Kaynakları Dergisi, 14(3), 43-64.

Khatri, N., Wen, C. Y., Fuei, L. W. ve Geok, T. A. (2008). Cronyism: Antecedents and consequences. 18 Ağustos 2018 tarihinde http://www.ntu.edu.sg/nbs/sabre/working papers/10-99.pdf adresimden erişilmiştir.

Konovsky, M. A. (2000). Understanding procedural justice and its impact on business organizations. Journal of Management, 26(3), 489-511.

Kwon, I. (2006), Endogenous favoritism in organizations. University of Michigan Topics in Theoretical Economics, 6(1), 1-24.

Loi, R., Yang, J. ve Diefendorf, J. M. (2009). Four-factor justice and daily job satisfaction: A multi-level investigation. Journal of Applied Psychology, 94, 770-781.

Meriç, E. (2012). Illköğretim okullarında görev yapan öğretmenlerin algılarına göre okul yönetiminde kayırmacılı. Yayınlanmamış yüksek lisans tezi. Yüzüncü Yıl Üniversitesi, Sosyal Bilimler Enstitüsü, Van.

Meriç, E. ve Erdem, M. (2013). İlköğretim okullarında görev yapan öğretmenlerin algılarına göre okul yönetiminde kayırmacılık. Kuram ve Uygulamada Ĕ̆gitim Yönetimi, 19(3), 467-498.

Özcan, K. (2014). Çevresel baskı gruplarının okul yönetimine etkileri: Adıyaman ili örneği. E-International Journal of Educational Research, 5(1), 88-113.

Özgan, H. (2011). Örgütsel davranış bağlamında öğretmenlerin örgütsel adalet, güven, bağlılık, yönetici değerlendirme ve çatışma yönetimi stratejileri algıları arasındaki ilişkilerin incelenmesi. Kuram ve Uygulamada Eğitim Bilimleri Dergisi, 11(1), 229-247. 
Özkanan, A. ve Erdem, R. (2014). Yönetimde kayırmacı uygulamalar: kavramsal bir çerçeve. Süleyman Demirel Üniversitesi Sosyal Bilimler Enstitüsü Dergisi, 20, 179-206.

Özler, D. E. ve Büyükarslan, A. (2011). The overall outlook of favoritism in organizations: A literature review. International Journal of Business and Management Studies, 3(1), 275-285.

Özsemerci, K. (2002). Türk kamu yönetiminde yolsuzluklar, nedenleri, zararları ve çözüm önerileri. Ankara: Sayıştay Yayınları.

Polat, S. (2007). Ortaöğretim öğretmenlerinin örgütsel adalet algıları, örgütsel güven düzeyleri ile örgütsel vatandaşlık davranışları arasındaki ilişki. Yayınlanmamış doktora tezi. Kocaeli Üniversitesi, Eğitim Bilimleri Enstitüsü, Kocaeli.

Polat, S. ve Kazak, E. (2014). Okul yöneticilerinin kayırmacı tutum ve davranışları ile öğretmenlerin örgütsel adalet algıları arasındaki ilişki. Kuram ve Uygulamada Eğitim Yönetimi, 1(1), 71-92.

Polat, S. ve Celep, C. (2008). Ortaöğretim öğretmenlerinin örgütsel adalet, örgütsel güven, örgütsel vatandaşılı davranışlarına ilişkin algıları. Kuram ve Uygulamada Ĕ̈itim Yönetimi, 54, 307-331.

Pounder, D. G. ve Blase, J. J. (1988). Principal favoritism: explanations, effects and implications for practice. University of Arkansas University Libraries, 19(1), 3-7.

Rutter, M. ve Maughen, B. (2002). School effectiveness findings 1979-2002. Journal of School Psychology, 40(6), 451-475.

Saylı, H. ve Kızıldağ, D. (2007). Yönetsel etik ve yönetsel etiğin oluşmasında insan kaynakları yönetiminin rolünü belirlemeye yönelik bir analiz. Afyon Kocatepe Üniversitesi Sosyal Bilimler Dergisi, 9(1), 231-251.

Şişman, M. ve Turan, S. (2004). Bazı örgütsel değişkenler açısından çalışanların is, doyumu ve sosyal-duygusal yalnızlık düzeyleri (MEB şube müdür adayları üzerinde bir araştırma), Osmangazi Üniversitesi Sosyal Bilimler Dergisi, 5(1), 117-128.

Şişman, M., Güleş, H. ve Dönmez, A. (2010). Demokratik bir okul kültürü için yeterlilikler çerçevesi. Uş̧ak Üniversitesi Sosyal Bilimler Dergisi, 3(1), 167-182.

Taşdan, M. ve Yılmaz, K. (2008). Organizational citizenship and organizational justice scales' adaptation to Turkish. Eğitim ve Bilim Dergisi, 33(150), 87-96.

Tol, J. E. V. (1991). Eros gone awry: Liability under title vii for workplace sexual favoritism. Industrial Relations Law Journal, 13(1), 153-182.

Yıldırım, M. (2013). Kamu yönetiminin kadim paradoksu: Nepotizm ve meritokrasi. СВÜ Sosyal Bilimler Dergisi, 11(2), 353-380. 


\section{Kaynakça Bilgisi / Citation Information}

Cesur, A. ve Erol, E. (2020). Okul yönetiminde kayırmacılık ve örgütsel adalet arasındaki ilişki: Afyonkarahisar ili örneği. OPUSUluslararası Toplum Araştırmaları Dergisi, 15(25), 3467-3496. DOI: 10.26466/opus.633508 